\title{
A Conferência como Estratégia Dramatúrgica de Desvio
}

\author{
João Alberto Lima Sanches \\ Universidade Federal da Bahia - UFBA, Salvador/BA, Brasil \\ E-mail: joaoright@gmail.com
}

\section{Resumo}

Este artigo discute estratégias dramatúrgicas que estruturam peças-conferência, ou conferências-espetáculo. O trabalho comenta exemplos dessas formas recorrentes na cena contemporânea e, como perspectiva teórica, baseia-se nas noções de crise do drama e desvio, formuladas respectivamente por Peter Szondi e por Jean-Pierre Sarrazac. O estudo também dialoga com o trabalho de outros artistas e teóricos como Fernando Kinas, Patrice Pavis e Cleise Mendes.

\section{Palavras-chave}

Peça-conferência. Dramaturgia contemporânea. Desvio.
This article discusses dramaturgical strategies that structure conference plays, or conference shows. The work comments on examples of these recurrent forms in the contemporary scene and, as a theoretical perspective, is based on the concepts of crisis of the drama and deviation, formulated respectively by Peter Szondi and JeanPierre Sarrazac. The study also dialogues with the work of other artists and theorists such as Fernando Kinas, Patrice Pavis and Cleise Mendes.

Keywords

Conference piece. Contemporary dramaturgy. Deviation. 
Em outubro de 2018, uma manchete do jornal Folha de São Paulo afirmava: "Peças usam tom de palestra na disputa pela atenção do público. Espetáculos sem grandes aparatos e feitos em tom de conversa tentam cativar audiência" (BARSANELLI, 2018). A matéria de Maria Luísa Barsanelli refletia sobre a curiosa recorrência de peças-conferência na cena contemporânea. A jornalista menciona como exemplos no Brasil naquele momento os espetáculos Mortos-Vivos - Uma Ex-Conferência, da companhia Foguetes Maravilha; Colônia, monólogo de Renato Livera com direção de Vinicius Arneiro; CérebroCoração de Mariana Lima; e Hamlet - Processo de Revelação, monólogo do coletivo Irmãos Guimarães com o ator Emanuel Aragão.

Importante destacar que, em 2018, também houve a estreia de Domínio Público, peça que reuniu quatros artistas atacados publicamente no ano anterior: Maikon $\mathrm{K}$, preso durante a performance $D N A$ de $D A N$, por ficar nú dentro de uma bolha transparente; Wagner Schwartz, criticado depois que uma criança, acompanhada pela mãe, tocou seu corpo durante a performance La Béte; Elisabete Fringer, coreógrafa e mãe da criança que tocou Schwartz; e Renata Carvalho, atriz transgênero do monólogo O Evangelho Segundo Jesus Rainha do Céu, censurado inúmeras vezes por meio de liminares na Justiça que impediram apresentações.

Embora Barsanelli não mencione Domínio Público, o espetáculo estreou naquele ano no Festival de Curitiba com um formato de colóquio. É composto de quatro conferências que partem de histórias relativas à Mona Lisa - reflexões sobre a obra em si, sobre a história da obra e sobre a trajetória de pessoas diretamente relacionadas à obra. O espetáculo-conferência discute o papel das artes e dos artistas na sociedade; a manipulação da informação; a censura e a intolerância, entre outras questões contemporâneas.

Também em 2018, estrearam em Salvador os espetáculos Como se tornar estúpido em 60 minutos e Revele! Um desabafo cômico. O primeiro é uma adaptação do romance francês Como me tornei estúpido (PAGE, 2005), do jovem escritor Mar- tin Page. A principal estratégia da adaptação foi transformar a história de Page, cheia de personagens e narrada em terceira pessoa, em uma aula performática onde o ator Rafael Medrado ensina o público a se tornar estúpido para alcançar a felicidade. Ao adotar o formato de conferência e o professor/palestrante como enunciador/protagonista, a dramaturgia estabeleceu uma dinâmica de costura que permitiu ao discurso operar os desvios necessários, de maneira direta. Mas, apesar de manter a enunciação para a plateia majoritariamente, tanto no texto como na encenação desta adaptação, há cenas com diálogos no modo dramático. Algumas cenas apresentam inclusive trocas de réplicas entre várias personagens e ao ator, em princípio, coube interpretar todas as vozes na montagem mencionada.

Já em Revele! Um desabafo cênico encontramos uma dramaturgia mais atravessada pelo real e que costura lembranças e comentários da atualidade. Realizado sob o pretexto de uma comemoração dos 40 anos de carreira do diretor baiano Fernando Guerreiro, o espetáculo se estrutura principalmente sobre o fato do artista sair da posição de diretor e subir ao palco para fazer revelações. Revele! conta com um roteiro prévio (dramaturgia assinada por Daniel Arcades), mas não há um texto decorado por Guerreiro, apenas uma ordem provisória dos assuntos. Guerreiro é diretor e também radialista, apresentador do popular programa Roda Baiana, da Rádio Metrópole de Salvador, e esse atravessamento do real é estruturante na dramaturgia do espetáculo. O título, por sinal, vem de seu bordão na rádio: "Revele!", diz sempre Guerreiro aos entrevistados. O espetáculo se configura como uma mistura de solo, stand up comedy, talk show, ou simplesmente performance autobiográfica baseada nas memórias e opiniões satíricas de uma grande referência do teatro na Bahia.

Embora a simultaneidade de muitas montagens com o mesmo perfil tenha chamado a atenção de artistas, teóricos e jornalistas, cabe ressaltar que o formato tem muitos precedentes e sugere associações com diferentes estratégias dramatúrgicas.

Em sua reportagem, Barsanelli (2018) destaca 
o despojamento material das encenações, as propostas de atravessamentos do real e, em relação à dramaturgia, a enunciação direta para a plateia. Ao invés de falarem entre si, as personagens, os atores e/ ou performers falam diretamente para/com o público, utilizando variadas estratégias discursivas que misturam gêneros próximos como palestra, bate-papo, depoimento, confissão, relato de experiência, entre outros. A jornalista curiosamente considera que, ao contrário de explorar a interação, essas formas recentes parecem "[...] deixar o público à vontade, imerso na encenação" (BARSANELLI, 2018, p. 1), evitando explorar a interatividade e investindo na proximidade, ou melhor, na empatia e na intensidade que a condição de proximidade e despojamento pode propiciar.

Barsanelli ainda cita o artigo Carta Aberta: uma peça conferência, numa cidade em repouso, para um banquete público (KINAS, 2005) do encenador e pesquisador Fernando Kinas, publicado na revista Sala Preta, para concluir que o formato seria uma alternativa para unir a cena poética à política:

Seja ao propiciar essa empatia emotiva
com o espectador, seja na conversa di-
reta com o público, a peça-palestra não
deixa de ser também uma resposta ao
conturbado clima social e político em que
vivemos nos últimos tempos. Uma tenta-
tiva de contornar a atual falta de diálogo,
em que muitos só ouvem o que querem
escutar. Precisamos, afinal, falar sobre
nós mesmos. (BARSARELLI, 2018, p. 2).

Além do exposto na reportagem, observemos diretamente o artigo de Kinas. Logo no início, o autor comenta o impacto que a publicação, em 1996, da Carta ao diretor de teatro, de Denis Guénoun, e sua posterior encenação no Festival de Avignon teriam causado na França. O texto, que também foi encenado no Brasil por Kinas, não apresenta elementos tradicionalmente dramáticos como conflito, intriga e personagens. A Carta encena sobretudo o próprio pensamento:

Entre ensaio e dramaturgia, a carta atualiza o debate sobre o "pensamento encenado".
No início do texto o autor faz algumas das referências de praxe sobre o tema: o Platão dos Diálogos, Diderot e seu Paradoxo sobre o Comediante, a Compra do Cobre de Brecht, e ainda as Rãs de Aristófanes, que embora seja uma "peça de teatro", mostra Ésquilo e Eurípides, nos infernos, debatendo a tragédia. Estas experiências híbridas, entre o dramático e o dramático em crise, $o$ entre o dramático e o pré e o pós-dramático - meu ponto de partida são as reflexões de Peter Szondi, Jean-Pierre Sarrazac e Hans-Thies Lehmann, além das investigações do próprio Guénoun -, seriam formas de apresentar, cenicamente, não mais personagens em ação, mas o próprio pensamento. Guénoun afirma que uma idéia, abstrata, pura, não é nada se ela não se mostra". Invocando Hegel, Guénoun quer forçar a idéia a sair de si, a se mostrar, nos palcos, sem frivolidades, nua. (KINAS, 2005, p. 209).

Baseando-se em Guénoun e também em Bernard Dort (2010), entre outros teóricos, Kinas ressalta o caráter de assembleia do ato teatral, sua natureza "agorística", a potência do encontro presencial para o debate coletivo e, consequentemente, para a vocação política: "[...] O modelo 'peça-conferência' é uma tentativa de pensar em cena, pensar poética e politicamente, assumindo sem tergiversação a convergência entre ética e estética" (KINAS, 2005 , p. 212). A peça-conferência então tenderia a valorizar essa dimensão presencial e política da cena, no nosso entender, a dimensão performativa.

No entanto, ao mencionar as noções de pré e pós-dramático, Kinas arrisca adotar uma perspectiva teleológica, comum aos teóricos Peter Szondi e Lehmann, mas da qual se distancia Sarrazac. Tal abordagem tende a associar os modelos dramáticos tradicionais (e até a ficção em geral) a uma suposta visão de mundo burguesa, individualista, associada ao status quo do capitalismo moderno: "Quando a forma dramática se enfraquece, e a ficção parece comprometida com a vulgaridade comercial e a banalidade televisiva, como evitar concessões ou a abdicação?" (KINAS, 2005, p. 212).

Não concordamos com abordagens que limitem ideologicamente o modo dramático, pois 
consideramos que uma mesma forma pode remeter a diferentes posições ideológicas a depender de seu contexto histórico e enunciativo. Também compreendemos que a crise do drama (SZONDI, 2011) é permanente e produtiva - a diversidade e radicalidade das dramaturgias moderna e contemporânea são provas disso. Portanto, não caberia tratar da superação, ou condenação de um modelo abstrato, ou de um único modo de criar e, sim, tentar compreender as transformações da forma dramática, seus incessantes transbordamentos.

Apesar dessa divergência pontual, convergimos com Kinas no sentido de reconhecer que as peças-conferências são exemplos emblemáticos de dramaturgias que, explicitamente, se desviam de modelos dramáticos tradicionais e expectativas majoritárias de recepção, expandindo o campo dos possíveis. Elas fazem parte daquilo que chamamos de dramaturgias de desvio (SANCHES, 2016). Reconhecemos também nesses textos e espetáculos, em seus desvios, a tentativa de uma abordagem política mais direta e efetiva.

No Dicionário da performance e do teatro contemporâneo de Patrice Pavis (2017), o verbete Conferência-Espetáculo (PAVIS, 2017, p. 64) comenta os atravessamentos entre arte e pedagogia que essas formas poéticas assumem, destacando sua dimensão política: "Percebe-se aí sempre uma crítica da instituição artística e escolar, uma vontade de não ser somente um artista, mas um ativista, um militante político, um espectador engajado" (PAVIS, 2017, p. 65). Tal percepção aponta para uma multiplicidade de práticas artísticas que exploram, desde o início do século passado, tensões entre discurso crítico e poético; entre institucionalidade artística, científica e seus contextos de produção. Também conhecidas como palestra-performance (CATALÃO, 2017), ou lecture performance (LIMA, 2017), essas ações fronteiriças indicam uma genealogia que inclui artistas como John Cage, Joseph Beuys e Robert Morris e são frequentemente identificadas como pertencentes ao campo da performance art. Este artigo, no entanto, concentra-se em alguns aspectos relaciona- dos especificamente à dramaturgia, a partir de produções teatrais brasileiras, por isso a preferência pelos termos peça-conferência e conferência-espetáculo.

Do ponto de vista dramatúrgico, Pavis (2017) considera que essas formas apresentam sofisticação teórica e virtuosidade artística, retomando a oposição clássica entre mostrar e jogar, imitar e narrar, dramático e épico. O teórico chama a atenção para a constância e para a ambiguidade das idas e vindas entre esses pólos que são operadas pela estratégia da conferência: "[...] elas estão no centro desse trabalho, do mesmo modo que se tornou central a confrontação entre teoria e prática" (PAVIS, 2017, p. 65).

É possível distinguir pelo menos cinco potenciais desvios dessas formas cênico-dramatúrgicas: a enunciação direta para o leitor/espectador; o hibridismo do discurso e seu caráter monodramático (encenação do pensamento); os atravessamentos do real; e o virtual despojamento de seus devires cênicos. Dos cinco, neste artigo, vamos nos concentrar no desvio mais explícito que é o endereçamento da enunciação para o leitor/espectador, o que, diga-se de passagem, não é exclusivo dessa forma contemporânea de dramaturgia.

Falar de frente recebeu, na história do teatro, diferentes nomes: monólogo, coral, apartes, canções ou songs, interpelação cômica dos espectadores. Mas o "endereço" pode se dar sem signos exteriores. E este é justamente um dos enigmas do teatro. A reflexão de Guénoun revela e valoriza a força inequívoca inerente ao endereço, um equivalente da "presença", em contraste com a "ação", a "imagem" e o "perfil". Endereçar é ser capaz de doar e de se doar num ato coletivo, compartilhado, comum. Na comunhão instaurada pelo teatro, mais do que na "representação”, é que residiria o poder (e o mistério) mundano do teatro. (KINAS, 2005, p. 210).

Segundo Sarrazac (2012, p. 69), nas dramaturgias modernas e contemporâneas, é recorrente a personagem se apresentar em estado de isolamento. Entre outros motivos, estaria o fato de que o universo interno das personagens tenderia a prevalecer sobre as relações interpessoais. Dessa maneira, mui- 
tas construções estariam contrariando a concepção dramática hegeliana que entende o diálogo como o recurso prioritário das personagens para expressarem umas às outras seu caráter, seus objetivos, suas discordâncias e imprimir, assim, um movimento efetivo à ação dramática. Dramaturgias do fim do século XIX como as de Ibsen, Strindberg e Tchékhov anteciparam o surgimento de dramaturgias como as de Beckett, nas quais o diálogo é ofuscado pelo monólogo, e que se tornaram frequentes a partir da segunda metade do século XX. Trata-se, no entanto, de um tipo diferente do monólogo clássico, pois o atual serve para "suspender" o diálogo dramático, ao invés de colaborar para a continuidade da progressão da ação. Nesse teatro de tendência estático-dinâmica, os conflitos são mais intrapsíquicos do que interpessoais. Citando a etimologia da palavra diálogo ("réplica à distância"), Sarrazac afirma que, a partir dos anos 1880, tudo se passa como se as "[...] personagens nunca estivessem na distância correta que permite o diálogo fundado na relação interpessoal" (SARRAZAC, 2012, p. 70-71). No drama moderno e contemporâneo, a relação entre as personagens se tornaria mais instável do que a de cada personagem com o espectador. As personagens, mais do que responderem umas às outras, dirigem-se para o espectador (a priori inexistente na tradição dramática rigorosa). Em outras palavras, é o espectador moderno que se acha em diálogo, não mais as personagens.

O diálogo interpessoal era, do começo ao fim, lateral, limitado ao pequeno círculo das personagens, recortado por detrás da quarta parede. Inversamente, uma grande parte da "aventura" do diálogo moderno, diálogo errante - e, veremos, diálogo profundamente heterogêneo - encontra essa virtude da frontalidade, de direcionar-se e por comunicação direta com o espectador, que havia em Shakespeare e Calderón, e até mesmo nas origens do teatro ocidental, na tragédia e na comédia da Grécia antiga. Nesse sentido, o diálogo moderno é realmente mais dialógico [...]" (SARRAZAC, 2017, p. 199).

Sarrazac questiona-se como é possível caracterizar esse texto dramático no qual - ao lado de lon- gos monólogos, de momentos de coralidade, de relatos, ou mesmo cartas, nomenclaturas, fragmentos de diários íntimos, entre outros materiais heterogê neos - subsistem contudo vestígios, manifestam-se reincidências de diálogo? Como dar conta dos textos escritos para o teatro nos quais os modos épico, lírico, argumentativo, em vez de se integrarem dialeticamente, permanecem relativamente autônomos e coexistem com ele? (SARRAZAC, 2012, p. 70-71).

Uma possibilidade é reconhecer a presença de um diálogo rapsódico no teatro moderno e contemporâneo, que costura e descostura modos poéticos e discursos diferentes e que é mediatizado por um operador implícito - o sujeito rapsódico - noção que procura ampliar e flexibilizar o conceito de sujeito épico de Peter Szondi, pois, além de demonstrador desvinculado da ação, o sujeito rapsódico apresenta-se como "[...] um sujeito dividido, ao mesmo tempo interior e exterior à ação" (Ibidem, p. 71). Ou seja, se na concepção clássica o dramaturgo tenderia a parecer ausente do drama, nas dramaturgias modernas e contemporâneas ele tem sua presença explicitada tanto na voz do rapsodo (que se sobrepõe às das personagens) quanto em seu gesto de montagem que articula os heterogêneos discursos, documentos e materiais que compõem a obra. Esse "outro diálogo", característico da contemporaneidade, é uma mistura da troca de réplicas tradicionalmente dramática com outros tipos de diálogo como o filosófico, o científico e o jornalístico. Um movimento de hibridização que expressa uma vontade de emancipar o diálogo dramático da univocidade, valorizar a confrontação de diferentes vozes, ou, como observa Sarrazac quando reflete sobre a impulsão do monólogo no teatro moderno e contemporâneo:

Reconstruir o diálogo sobre a base de um
verdadeiro dialogismo. Dar autonomia à
voz de cada um, inclusive àquela do au-
tor-rapsodo, e operar a confrontação dia-
lógica das vozes singulares de uma época.
Expandir o teatro fazendo os monólogos
dialogarem [...] (SARRAZAC, 2012, p. 73). 
Esse "outro diálogo", que se dá quase que diretamente entre o dramaturgo e o leitor/espectador, é uma estratégia recorrente de muitos textos na cena contemporânea e fica ainda mais explícito nas referidas peças-conferência. Curioso observar, que, paradoxalmente, "[...] é a separação, o isolamento de cada locutor que irá servir de base para a edificação desse novo tipo de diálogo. A insularidade das personagens abre espaço para uma verdadeira polifonia" (SARRAZAC, 2017, p. 201).

Sabemos que os recursos dramatúrgicos do monólogo, do aparte e da narração são tão antigos quanto a arte teatral, mas suas aparições nas dramaturgias contemporâneas têm como particularidade essa tentativa de relativizar os discursos, de fugir da univocidade, de colocar diferentes vozes e pontos de vistas em evidência e confronto. Além disso, a natureza dos endereçamentos para a plateia constitui a principal situação dramática de muitas peças recentes, em muitos casos, a única situação.

\section{A conferência como situação dramática}

Nas duas versões do pequeno monólogo Os Males do Tabaco (TCHÉKHOV, 2003), a primeira de 1887 e a segunda de 1902, o dramaturgo russo Anton Tchékhov apresenta a hilária palestra de um fumante que foi coagido por sua mulher a fazer uma palestra contra o fumo: "Como assunto da minha conferência de hoje escolhi, por assim dizer, os males que acarreta à humanidade o uso do tabaco. Eu mesmo fumo, mas minha mulher mandou-me falar hoje sobre os males do tabaco e, sendo assim, não há o que discutir" (TCHÉKHOV, 2003, p. 160). O conferencista Niúkhin enrola e acaba discorrendo sobre diversos tópicos com exceção daquele que deveria abordar. Com muita ironia, a personagem usa a oportunidade para desabafar e reclamar da mulher, das filhas e de sua condição:

Fazendo aqui esta conferência, pareço estar alegre, mas no íntimo tenho ganas de gritar até perder a voz ou sair voando para algum lugar no fim do mundo. E não tenho a quem me queixar, até vontade de chorar eu sinto... Os senhores diriam: tem as filhas... Qual o quê! Falo com elas, e só fazem dar risadas... [...] (Olha ao redor.) Sou um infeliz, tornei-me um imbecil, um inútil, mas, no fundo, os senhores estão vendo diante de si o mais feliz dos pais. No fundo, é assim que deve ser e eu não ouso dizer o contrário. Se os senhores soubessem! Estou vivendo há 33 anos com minha muIher e, posso dizer, que foram os melhores anos de minha vida, nem todos os melhores, mas, no geral, foram assim. [...] (Olha ao redor.) Por sinal, parece que ela ainda não chegou, não está aqui e pode-se falar à vontade... (TCHÉKHOV, 2003, p. 163).

Com Os Males do Tabaco, podemos observar o pioneirismo de Tchékhov também na utilização da conferência como estratégia dramatúrgica de desvio. Fernando Kinas (2005) contribui para uma genealogia possível desse procedimento ao mencionar em seu artigo, como parentes mais velhos da tendência atual, as peças Insulto ao público de Peter Handke e Descrição de imagem de Heiner Müller, textos publicados respectivamente em 1966 e 1984. No entanto, é importante destacar uma diferença entre eles e a peça de Tchékhov: os textos de Handke e Muller aproximam-se mais pela enunciação direta de um discurso híbrido e polifônico do que por uma situação dramática (ficcional) "de conferência". A rigor, tais textos sequer apresentam uma situação dramática definida, em vez disso, parecem jogar com as possibilidades da enunciação direta para o leitor/espectador e com os transbordamentos entre realidade e ficção.

Em Insulto ao público, por exemplo, quatro oradores (cuja divisão enunciativa do texto o autor deixa em aberto), como um coro contemporâneo, proferem uma espécie de "prólogo", ou "insulto" à platéia, embora a rubrica inicial da peça indique que "Eles dirigem seus olhares ao público, mas sem parar sobre um espectador em especial" (HANDKE, 2015, p. 91). Logo, o público é "insultado" coletivamente, ninguém corre o risco de se ofender em particular lembremos de Barsanelli e sua percepção de certa recusa à interatividade nas atuais peças-conferência. De fato, a partir de uma enunciação coral, a peça 
de Handke performa um jogo de esvaziamento do sentido das palavras e da representação, problematizando a passividade dos espectadores e uma série de expectativas majoritárias no teatro e fora dele:

Sejam bem-vindos.

Esta peça é um prólogo.

Vocês não ouvirão nada que não tenham ouvido aqui antes.

Vocês não verão nada que não tenham visto aqui antes.

Vocês não verão nada do que sempre tem sido visto aqui.

Vocês não ouvirão nada do que sempre tem sido ouvido aqui.

Vocês ouvirão o que vocês habitualmente veem.

Vocês ouvirão o que vocês habitualmente não veem.

Vocês não verão nenhum espetáculo.

Suas curiosidades não serão satisfeitas.

Vocês não verão nenhuma peça.

Não haverá aqui nenhuma representação. Vocês verão um espetáculo sem cenas.

(HANDKE, 2015, p. 92).

Peça-provocação, "denúncia" da ficção, Insulto ao público estabelece claramente o endereçamento do discurso para a plateia, instalando, ainda que de maneira metadramática, uma situação determinada. Já em Descrição de imagem, de Heiner Müller, não é possível determinar sequer o próprio endereçamento, muito menos seu devir cênico. O texto começa da seguinte maneira:

\begin{abstract}
Uma paisagem entre estepe e savana, o céu de um azul prussiano, duas nuvens imensas flutuando lá dentro, como que unidas por esqueletos de arame, em todo caso de estrutura desconhecida, a maior, da esquerda, poderia ser um animal de borracha de um parque de diversões que se desgarrou de seu guia, ou um pedaço da Antártida em seu vôo de regresso, no horizonte uma serra plana, à direita na paisagem uma árvore, [...]. (MÜLLER, 1993, p.153)
\end{abstract}

Só há uma única rubrica, no final do texto, em que o autor se refere à peça da seguinte forma: "O texto descreve uma paisagem vista de além-túmulo. A ação é livre, já que as seqüências são pas- sado, explosão de uma lembrança numa estrutura dramática morta." (MÜLLER, 1993, p.159). Insulto, prólogo, descrição, lembrança, estrutura dramática "morta". Handke e Müller performam, com suas dramaturgias, um transbordamento do próprio drama, ou mesmo um aniquilamento das noções de gêneros literários e, com elas, do modelo dramático absoluto. Esses textos apontam, problematizam e desviam-se do dramático e do canônico, ao mesmo tempo em que abrem as possibilidades do drama para além da encenação de uma ação interpessoal no presente. Como afirmou Kinas (2005), esses textos colocam em cena, sobretudo, o próprio pensamento.

No Brasil, em uma linha mais próxima de Os Males do Tabaco de Tchékhov - que adota a conferência como situação dramática, ficcional - devemos mencionar o bem-sucedido monólogo Apareceu a Margarida. A peça foi escrita em 1971, estreou em 1973, com direção de Aderbal Freire-Filho e interpretação de Marília Pêra, e proporcionou projeção internacional ao dramaturgo carioca Roberto Athayde. A peça teve uma carreira internacional impressionante, foi montada por grandes intérpretes como Marília Pêra, no Brasil; Marilu Marini, na Argentina; Anne Girardot e Madeleine Robinson, na França; Estelle Parsons, nos Estados Unidos, entre outras. A partir de uma situação semelhante à da personagem de Tchékhov, a irreverente professora Dona Margarida profere duas aulas para uma turma (a plateia), sempre tergiversando, fugindo da matéria, às vezes simulando solidariedade para, logo em seguida, desembocar numa retórica repressiva e totalitária. A dramaturgia, carregada de ironia, opera uma dinâmica de alternância brusca entre os discursos solidário e autoritário de Dona Margarida, que se tornou uma personagem antológica do teatro brasileiro:

Incompetentes! Vagabundos! Só pensam em sacanagem! O que vocês querem é que eu ensine a vocês os fatos da vida! Pois fiquem sabendo que não vou ensinar! Não vou ensinar mesmo! Vão aprender na casa do cacete! Não pensem vocês que eu vou me abrir toda na frente de vocês! Toda aberta, despida! Nada disso vai acontecer! 
Quero muita disciplina e muita ordem dentro desta sala! Vocês estão aqui dentro para aprender e não para se divertir! Ouviram bem! Isso aqui não é divertimento! Nada disso tem graça nenhuma! (Pausa) Mas dona Margarida não quer se dura com vocês... (Pausa) Já disse que não quero ser dura com vocês. Só há uma maneira de atingir um bom rendimento no ano letivo. É através de uma atmosfera de compreensão, de entendimento. Só assim nós podemos comungar nos nossos ideais de progresso e ordem. Só assim vocês vão entrar no curso ginasial. (ATHAYDE, 2003, p. 141-142)

Em Salvador, nos anos 1990, outra professora também ficou célebre e entrou para galeria das personagens mais queridas do teatro baiano: Dona Ivone Brandão, do monólogo Oficina Condensada. Sucesso de crítica e de público, dentro e fora da Bahia, o espetáculo ficou em cartaz durante $10 \mathrm{dez}$ anos e promoveu o trabalho de Rita Assemany, Fernando Guerreiro e Aninha Franco (respectivamente atriz, diretor e autora da peça) em todo país. Sob o pretexto de traçar um amplo painel sobre a condição feminina, a professora Dona Ivone Brandão realiza uma "oficina condensada", apresentando informações históricas e fazendo reflexões que revelam enfoques sobre o tema. As teses da conferencista maluca, que nos intervalos das lições vende muambas para complementar a renda, são alternadas com cenas (interpretadas pela própria) de personagens históricas como: a francesa Charlotte Corday, assassina do revolucionário Marat; Lisístrata; Safo; Messalina; e a condessa Alcira que Voltaire imortalizou como adúltera. A dramaturgia ainda faz alusões a Schopenhauer e Santo Agostinho. Nesses momentos, o espetáculo assume uma atmosfera de gravidade e lirismo, para logo em seguida retomar o clima predominantemente descontraído e que culmina numa verdadeira celebração da condição feminina.

É possível identificar em Salvador diversas peças que seguem essa tendência a um endereçamento externo, a uma interlocução direta com o público, sem que haja uma narrativa central, ou fábula a ser encenada. Outro exemplo de sucesso é o monólogo O Indignado, de 2008, interpretado por Frank Menezes. Os autores da peça, Claudio Simões e Djaman Barbosa, criaram uma estrutura que remete aos tradicionais shows de humor ou mesmo aos atuais stand up comedies, mas com um discurso político mais exacerbado do que normalmente encontramos nesse tipo de dramaturgia.

No referido texto, uma personagem-ator indignada - no caso, o ator baiano Frank Menezes (assume-se esse atravessamento do real no texto e na encenação) - desabafa com a plateia, comentando e reclamando de diversos aspectos da vida contemporânea, sem a preocupação de contar uma história específica. A continuidade do discurso não se dá em função de uma narrativa, pelo contrário, são assuntos diversos que são abordados de maneira fragmentada e pontual, numa espécie de montagem de pequenas histórias, de pequenos "casos", que são alvo dos comentários satíricos e da desconstrução de Frank. Vejamos o trecho inicial da peça:

FRANK - Vocês acham que eu devo fazer uma plástica? Mudar o meu nariz? Que é que vocês acham? Não ria não, é sério. Uma amiga me sugeriu outro dia. Ela disse, "Frank, você devia fazer uma plástica! Hoje em dia a gente pode corrigir pequenas imperfeições, etecétera". Eu perguntei: "Que imperfeições?" Ela riu, como se estivesse na cara. Eu perguntei de novo: "Que imperfeições?" E ela disse: "Tá na cara!" Eu não agüentei e ameacei: "Ou você fala ou eu te deixo aqui no meio da Paralela" - ela tava de carona. Ela, na maior naturalidade, disse: "Seu nariz, por exemplo." (Indignado) O que é que tem o meu nariz? Ela riu de novo! (Mais indignado.) Responda, o que é que tem o meu nariz? Ela me olhou e disse: "Que cara de pau!" (Ainda mais indignado) Cara de pau por quê? (Amiga.) "Esse seu nariz não vai te levar pra lugar nenhum, né, Frank?" Eu que quase não levava ela pra lugar mais nenhum e despejava ela lá no meio da Paralela, chovendo. Mas aí eu comecei a pensar: será? Ela viu que a minha cara não tava boa. Aliás, pra ela a minha cara não devia nunca tá boa, né? Ela viu meu mau humor e tentou fechar o assunto: "Todo mundo precisa de alguma plástica”. Mas eu não sou todo mundo, eu sou um ator. Eu tenho mais de vinte anos de profissão... com esse nariz. 
Eu fiz as duas peças de maior sucesso do teatro baiano até hoje, fiz cinema, fiz tevê... com esse nariz. Mas vocês não acham que eu seria bem melhor ator com um nariz menor? E o sorriso? Será que não tá na hora de recapear tudo, fazer clareamento a laser? Tem que ser a laser, que tudo agora é a laser. Tatuagem: a laser; tirar gordura: a laser; depilação: a laser; dentes brancos: a laser. Fui fazer o clareamento: não pode tomar café, não pode tomar açaí, não pode comer chocolate, tomar vinho, suco de uva, comer feijão. Doutor, e fuder, pode? Graças a Deus! (BARBOSA; SIMÕES, 2013, p. 265).

Oito anos depois, no início de 2016, Frank volta ao formato com o monólogo O Corrupto, agora assinando sozinho a autoria do texto. Na montagem, o ator interpreta um professor de corrupção ativa que dá aulas para uma turma repetente, a plateia, que está em recuperação por não conseguir atingir os níveis necessários para ser aprovada no curso. A dramaturgia de $O$ Corrupto utiliza ficcionalmente a situação dramática de uma aula como o faz Tchékhov, Athayde e Aninha Franco em, respectivamente, Os Males do Tabaco, Apareceu a Margarida e Oficina Condensada.

Por conta dos comentários satíricos, ou mesmo do ato explícito de narrar e/ou "costurar" rapsodicamente diversos temas e assuntos, é possível associar a estrutura e a linguagem dos textos $O$ Indignado e O Corrupto aos desvios de tendência mais épica. Diferentemente, em outro sucesso do teatro baiano, o monólogo A Casa da Minha Alma de Aninha Franco, de 2003, por exemplo, também temos uma personagem-atriz "desabafando" com a plateia, como em $O$ Indignado, numa dramaturgia rapsódica, mas com linguagem e estrutura que tendem mais ao lírico.

Na peça, uma atriz (no caso, Rita Assemany) se dirige ao público para anunciar que não fará o espetáculo. Numa espécie de crise de identidade, ela decide vagar pela casa de ensaio para refletir sobre a situação. Essa casa de ensaio era a "Casa 14", um espaço com três pavimentos, salas de ensaio e acervo cenográfico, que fica ao lado do antigo Theatro XVIII no Pelourinho, em Salvador. Rita Assemany convida o público a acompanha-la nesse péri- plo. Com uma linguagem poética, rica em imagens e citações, misturando (montando) textos da autora e pequenos trechos de outros autores, a dramaturgia de Aninha Franco (2013) apresenta uma atriz que dirige seu discurso todo tempo ao público com o qual se desloca pela casa. O texto é dividido em "passos" que correspondem aos diferentes espaços da casa (entrada, escada, acervo de figurino, palco, plateia etc.). A cada "passo", são feitas associações entre o espaço ocupado e as questões que afligem a personagem, sem nenhuma causalidade muito aparente.

Uma passagem do artigo O Drama Lírico de Cleise Mendes pode servir como síntese para algumas das diferenças e das semelhanças entre os monólogos $O$ Indignado, O Corrupto e A Casa da minha Alma cuja linguagem associamos a uma tendência mais lírica:

A unificação de tempo, espaço e ação no drama prende-se a uma motivação totalmente oposta à concentração do foco lírico. Esse se sustenta por uma comunhão, uma perfeita intimidade entre o sujeito e o objeto, e, consequentemente, gera o mesmo sentimento no leitor do poema. O drama, ao contrário, alimenta-se do conflito, do antagonismo, da agonia do choque entre vontades contrárias. Daí que a manutenção da unidade espacial e temporal é uma exigência de manter coesa, circunscrita num dado limite, uma força que tende fazer explodir as fronteiras da obra. Qualquer quebra dessas unidades no drama indica imediatamente a intromissão de recursos épicos. Já a presença do lírico na obra dramática atinge principalmente a linguagem e o modo de encadeamento das situações, quebrando o nexo causal que as faria desfilar numa sequência lógica Em termos estruturais, a hibridização lírico-dramática atinge sobretudo o argumento da peça, reduzindo a intriga a uma única situação basica e recorrente. (MENDES, 1981, p. 56).

Observamos nas diferentes peças mencionadas até aqui a recorrência da simples situação (dramática, performativa, concreta) de falar para uma platéia, diretamente, como a principal estratégia dramatúrgica. Seja dramatizando uma conferência, fictícia, ou assumindo uma condição metadramática e os atravessamentos do real, todos os textos e espetáculos 
comentados adotam "falar para uma plateia" como procedimento estruturante. Esse "outro diálogo" que já comentamos, nas peças-conferência, não é apenas mais um recurso, ou desvio, a enunciação direta para o público nessas dramaturgias é estratégica e isso talvez seja o que as caracteriza mais precisamente.

\section{Considerações finais}

Seja com uma inclinação mais ao épico, ou ao lírico, ou mesmo combinando elementos relativos a tendências diversas, as dramaturgias contemporâneas expressam esse movimento rapsódico, esse "outro diálogo" contemporâneo, que problematiza a noção tradicional de diálogo dramático justamente por estabelecer a comunicação entre o dramaturgo (que pode ser coletivo, ou o próprio ator, performer, artista enunciador) e o espectador de maneiras cada vez mais diretas. Uma consequência dessas estratégias é que elas tendem a tornar as personagens cada vez menos necessárias na mediação dramática. Como afirmou Ryngaert, a personagem contemporânea "[...] ainda fala, mas nem sempre se sabe de onde isso vem, por falta de referências sociais, psicológicas, ou simplesmente de identidade afixada" (RYNGAERT, 1998, p. 136).

Mesmo com o eventual "enfraquecimento" da personagem e da noção de diálogo dramático como troca de falas entre as personagens, a dramaturgia ainda se baseia na interação verbal, no discurso do "outro", já que a linguagem se funda na possibilidade de uma interlocução. E, no caso da dramaturgia, essa interlocução é mediatizada por uma personagem, um ator, um performer ou por um simples enunciador - o que cria o jogo primordial do drama como acontecimento estético-comunicativo: "[...] os sujeitos que interagem parecem ser a fonte natural das emissões, autores absolutos de suas enunciações" (MENDES, 2011, p. 2). Mesmo quando submetidos ao olhar e à condução de um narrador, mesmo quando eles, esses "seres de papel", ou os artistas que os encarnam, são seus próprios narradores, comentadores, criadores, esses sujeitos que intera- gem, por isso mesmo, nunca estão completamente sozinhos. A interação enunciativa é o que os define, mesmo nos monólogos onde o sujeito dirige sua fala a "si mesmo" e a interlocutores imaginários. Esse "si mesmo" e seus interlocutores representam as diversas vozes que atravessam e compõem o discurso.

Existe um dialogismo de menor dimensão, compatível com esse homem separado. Cada homem é um diálogo, todo monólogo é um diálogo, afirmava Mallarmé. E é bem essa pluralidade de vozes no interior de um mesmo solilóquio que confere sua dimensão dialógica a um grande número de peças modernas e contemporâneas. (SARRAZAC, 2017, p. 205).

Uma personagem dramática (como qualquer pessoa) sempre fala com e para alguém, o discurso do outro não apenas atravessa e motiva sua fala, a personagem recebe desse discurso a própria justificativa para sua presença, para sua existência, pois, como afirma Cleise Mendes (2011, p. 3), "sem o outro, não há drama, tampouco há possibilidade de existência”.

Referências

ATHAYDE, Roberto. As peças precoces: Apareceu a Margarida e outras. Rio de Janeiro: Nova Fronteira, 2003.

BARBOSA, Djaman; SIMÕES, Cláudio. O indignado. In: SANCHES, João. A crise do drama entre nós: uma reflexão sobre dramaturgias contemporâneas encenadas em Salvador. Salvador: Escola de Teatro da UFBA, 2013.

BARSANELLI, Maria Luisa. Peças usam tom de palestra na disputa pela atenção do público. Folha de S. Paulo, 2018. Disponível em: https://www1.folha. uol.com.br/ilustrissima/2018/10/pecas-usam-tom-de-palestra-na-disputa-pela-atencao-do-publico.shtml. Acesso em: 06 jan. 2020. 
CATALÃO, Marco. Uma genealogia para a palestra-performance. Urdimento, Florianópolis, v. 1, n. 28, p. 4-14, jul. 2017. Disponível em: https://doi.org/10.596 5/1414573101282017004. Acesso em: 17 jul. 2020.

DORT, Bernard. O teatro e sua realidade. São Paulo: Perspectiva, 2010.

FRANCO, Aninha. A casa de minha alma. In: SANCHES, João. A crise do drama entre nós: uma reflexão sobre dramaturgias contemporâneas encenadas em Salvador. Salvador: Escola de Teatro da UFBA, 2013.

HANDKE, Peter. Peter Handke: peças faladas. São Paulo: Perspectiva, 2015.

KINAS, Fernando. Carta Aberta: uma peça conferência, numa cidade em repouso, para um banquete público. Sala Preta, São Paulo, v. 5, p. 209-214, 28 nov. 2005. Disponível em: https://doi.org/10.11606/ issn.2238-3867.v5i0p209-214. Acesso em: 20 mai. 2020.

LIMA, Manuel Pessoa de. Institutional critique and the lecture performance. Unlikely: Journal for Creative Arts, 2017. Acesso em: 17 jul. 2020.

MENDES, Cleise Furtado. O drama lírico. ART Music Review, Salvador, v. 2, n. 2, p. 47-67, jul./set. 1981.

O diálogo no drama e o discurso do outro. In: Anais do VII ENECULT, 2011. Salvador. VII ENECULT. Salvador: Pós-Graduação em Cultura e Sociedade, UFBA, 2011.

MÜLLER, Heiner. Medeamaterial e outros textos. Rio de Janeiro: Paz e Terra, 1993.

PAGE, Martin. Como me tornei estúpido. Rio de Janeiro: Rocco, 2005.
PAVIS, Patrice. Dicionário da performance e do teatro contemporâneo. São Paulo: Perspectiva, 2017.

RYNGAERT, Jean-Pierre. Ler o teatro contemporâneo. São Paulo: Martins Fontes, 1998.

Dramaturgias de desvio:recorrências em textos encenados no Brasil entre 1995 e 2015. 2016. Tese (Doutorado em Artes Cênicas). Escola de Teatro da UFBA. Salvador, p. 251. 2016. Disponível em: https://repositorio.ufba.br/ri/bitstream/ri/19583/1/TESEJOÃ

SARRAZAC, Jean-Pierre et al. (Orgs.). Léxico do drama moderno e contemporâneo. Tradução de André Telles. São Paulo: Cosac Naify, 2012.

SARRAZAC, Jean-Pierre. Poética do drama moderno: de Ibsen a Koltès. 1. ed. Tradução de Newton Cunha, Jacó Guinsburg e Sonia Azevedo. São Paulo: Perspectiva, 2017.

SZONDI, Peter. Teoria do drama moderno (18801950). 2. ed. Trad. Raquel Imanishi Rodrigues. São Paulo: Cosac Naify, 2011.

TCHÉKHOV, Anton P. Os males do tabaco e outras peças em um ato. São Paulo: Ateliê Editorial, 2003.

Recebido: 20/05/2020

Aceito: $16 / 07 / 2020$

Aprovado para publicação: 17/11/2020 
Este é um artigo de acesso aberto distribuído sob os termos de uma Licença Creative Commons Atribuição 4.0 Internacional. Disponível em: $<$ http://creative commons.org/licenses/by/4.0>.

This is an open-access article distributed under the terms of the Creative Commons Attribution License 4.0 International. Available at: <http://creative commons.org/licenses/by/4.0>.

Ce texte en libre accès est placé sous licence Creative Commons Attribution 4.0 International. Disponible sur: <http://creativecommons.org/licenses/by/4.0>. 